\title{
Observed Performance of Highway Embankment over Soft Marine Clay: A Case Study in Wenzhou, China
}

\author{
Xia Bian, ${ }^{1,2}$ Jin-Kai Yan $\mathbb{D D}^{3}{ }^{3}$ and Wei Zhang ${ }^{2}$ \\ ${ }^{1}$ Institute for Underground Space and Geoenvironment, School of Earth Sciences and Engineering, Nanjing University, \\ Nanjing 210046, China \\ ${ }^{2}$ Key Laboratory of Ministry of Education for Geomechanics and Embankment Engineering, Hohai University, \\ Nanjing 210098, China \\ ${ }^{3}$ Chinese Academy of Geological Sciences, Beijing 100037, China
}

Correspondence should be addressed to Jin-Kai Yan; yanjinkaisw@163.com

Received 4 June 2020; Revised 10 July 2020; Accepted 24 July 2020; Published 11 August 2020

Academic Editor: Wen-Chieh Cheng

Copyright $(2020$ Xia Bian et al. This is an open access article distributed under the Creative Commons Attribution License, which permits unrestricted use, distribution, and reproduction in any medium, provided the original work is properly cited.

This paper presents a case history of observed performance of highway embankment over soft marine clay in Wenzhou, China. During the embankment construction, the changes of ground settlement, ground displacement, and lateral displacement of subsoil with the construction time were monitored and analyzed. The monitoring results indicate that the ground settlement and lateral displacement of subsoil account for about $75 \%$ in the process of embankment construction. The measured maximum values of ground settlement, ground displacement, and lateral displacement of subsoil are $37.88 \mathrm{~mm}, 21.50 \mathrm{~mm}$, and $23.56 \mathrm{~mm}$, respectively. After the completion of the embankment construction, the settlement gradually tended to be stable. It is suggested that the monitoring data of settlement and displacement of embankment are smaller than the design requirements, and the embankment stability is also ensured.

\section{Introduction}

Wenzhou is located in the southeastern coastal area of China, and the Feiyun River flows through Wenzhou. Most of the areas near the Feiyun River are alluvial deposits formed in Quaternary [1-4]. The Quaternary alluvial deposits have a high water content, high compressibility, and lower carrying capacity [5-9] and maybe induce many incidents during engineering construction [10]. Normally, this clay alluvial deposit consists of predominated clay mineral such as illite, smectite, and kaolinite [11, 12], resulting in poor engineering characteristics [13]. When highway embankments are constructed on alluvial deposits, the soft soils often bear intolerably large settlements or fail due to insufficient bearing capacity. Therefore, a variety of methods have been used to solve these problems [14-18]. Such reinforcement methods include jet grouting [2, 18-20], deep mixing [21-23], and stiffening method [24, 25]. According to different regional environment and different geological conditions, each method of foundation treatment has its scope of application.

Recent composite foundation is widely used for the construction of embankments on soft ground [26, 27]. Geosynthetics (such as geotextiles and geogrids) with high tensile strength, low elongation, and high stiffness are laid at the bottom of embankment which form reinforced cushion with gravel to maintain the integrity and continuity of the base [28-30]. Reinforced cushion and concrete pile constitute composite foundation of reinforced pile group. The reinforcement effect of geosynthetics on soft soil is mainly reflected in horizontal reinforcement. The reinforcement principle of geosynthetics reinforced cushion is as follows [31, 32]:

(1) It can increase the integrality and stiffness of cushion and adjust uneven settlement

(2) Due to the influence of the increase of cushion stiffness, it enlarges the range of load diffusion and makes the stress uniformly distributed 
(3) The lateral deformation of the underlying soft soil foundation is restrained

In this paper, a case history of observed performance of highway embankment over soft marine clay in Wenzhou, China, was presented. The plain concrete piles were used to support soft soil embankment. The changes of ground settlement, ground displacement, and lateral displacement of subsoil with the construction time were monitored. After the completion of the embankment construction, the settlement gradually tended to be stable. It is suggested that the monitoring data of settlement and displacement of embankment are smaller than the design requirements.

\section{Site Conditions}

2.1. General Situation of Engineering. The test site was located in the southwest of Zhejiang Province, in the middle and lower reaches of the Feiyun River (Figure 1). The length and width of the selected line were 364 and $17 \mathrm{~m}$. The expressway was constructed on soft soil. The profile of the main soil is shown in Figure 2. There is a $1 \mathrm{~m}$ thick coarse grained fill overlying a $4 \mathrm{~m}$ thick deposit of silty clay; this deposit overlies mud layer that is approximately $6 \mathrm{~m}$ thick. Underneath the mud layer is a mucky clay layer that is about $4 \mathrm{~m}$ thick followed by a clay breccia layer. The ground water level is at a depth of $2 \mathrm{~m}$. Based on the Unified Soil Classification System (USCS), the three types of soils can be classified as low plasticity clay (CL; [33]). The available detailed test data are shown in Figure 2, including the water content, the void ratio, and the unit weight to a depth of about $16 \mathrm{~m}$ below ground level. The mud layer has the characteristics of low strength, high compressibility, and high water content. Its void ratio is greater than 1.5. And its water content is between $50 \%$ and $65 \%$, usually higher than the liquid limit. Compared with the mud layer above, the water content of the mucky clay layer is lower than the liquid limit, and the void ratio is between 1 and 1.5 .

\subsection{Embankment Design and Pile Support Reinforcement.} The starting point of the route was connected to the 56 provincial highway, and the terminal was connected to the bridgehead approach, with a total length of $364 \mathrm{~m}$. The embankment filling height was about $3.0-5.5 \mathrm{~m}$. The embankment was $5.5 \mathrm{~m}$ high. The width of the road was $17 \mathrm{~m}$. The side slope of the embankment was $1 \mathrm{~V}$ to $1.5 \mathrm{H}(\mathrm{V}$, vertical; $\mathrm{H}$, horizontal). The embankment was supported by cast-in-place circular plain concrete pile that was formed from a low-slump concrete with a minimum of compressive strength of $15 \mathrm{~N} / \mathrm{mm}^{2}$. The circular plain concrete piles were $19 \mathrm{~m}$ in length and were founded on a relatively harder clay breccia layer (Figure 3(a)). It had a diameter of $0.5 \mathrm{~m}$ which was formed with the low-slump concrete. The piles were placed in a square grid with a center-to-center spacing of $2 \mathrm{~m}$. The pile caps had a dimension of

$1.2 \mathrm{~m} \times 1.2 \mathrm{~m} \times 0.35 \mathrm{~m}$ (length $\times$ width $\times$ height) that were formed from a minimum of compressive strength of $20 \mathrm{~N} / \mathrm{mm}^{2}$ of concrete and reinforcement bar with diameter of $12 \mathrm{~mm}$. Soil-rock mixture was used as the fill material for the embankment. According to the Technical Specifications for Construction of Highway Subgrades [34], the ratio of soil and rock by weight is designed as $6: 4$. Two layers of steel wire mesh were used together with gravels to form a $0.5 \mathrm{~m}$ thick load transfer platform as shown in Figure 3(c). The bottom layer of the steel wire mesh was $0.3 \mathrm{~m}$ from the base, and the second layer was $0.5 \mathrm{~m}$ above the first. The tensile strength of the steel wire mesh was $100 \mathrm{kN} / \mathrm{m}$ in both longitudinal and transverse directions. The maximum allowable tensile strain was 3\% [35]. The design value of the ultimate pile capacity in this project is about $960 \mathrm{kN}$, while the allowable pile capacity is about $800 \mathrm{kN}$. The key construction process of the plain concrete pile is as follows:

(1) After surface cleaning, the pile rig was placed according to the designed pile position. Pile rig must be level and stable. The immersed pipe was perpendicular to the ground to ensure that the deviation of verticality was not more than $1 \%$.

(2) The casing pipe was constructed and sunk to the predetermined elevation. During the sinking process of the casing pipe, the current on the ammeter was recorded once per $1 \mathrm{~m}$ sinking. The change of soil layer was explained.

(3) When the immersed pipe reached the design elevation, the material was fed into the pipe immediately until the mixture was level with the inlet. The mixture was formulated according to the design mix ratio and the concrete slump was controlled between 3 and $5 \mathrm{~cm}$.

(4) The immersed pipe should vibrate while pulling out, each pulling $0.5-0.1 \mathrm{~m}$, retaining vibration for 5-10 $\mathrm{s}$. The upward speed of immersed pipe was not more than $1.0 \mathrm{~m} / \mathrm{min}$, and it was evenly pulled up. If there was silt or silty soil, the rate of pipe pulling should be slowed down and controlled within $0.5 \mathrm{~m} / \mathrm{min}$. Reverse insertion was not allowed in the process of pulling out the casing pipe. If the supply material was insufficient, concrete should be poured while casing pipe is pulled up. With this method, the top standard of pile can reach the design requirement.

(5) After the immersed pipe was pulled out of the ground, it was confirmed that the pile reached the design height requirement. The steel reinforcement of pile cap was embedded; then, the casing pipe was moved to carry out the next pile construction.

The piles in this study are friction piles. During the construction of these piles, there exist some problems, such as diameter shrinkage and incline of pile center line. In order to avoid these problems, the casing pipe was used to complete the perfusion of concrete and was pulled out slowly after the completion of the perfusion of concrete; meanwhile, the verticality inspection was also conducted to ensure the verticality of the pile.

Based on the Specifications for Design of Highway Subgrades [34], the factor of safety (FOS) of the 


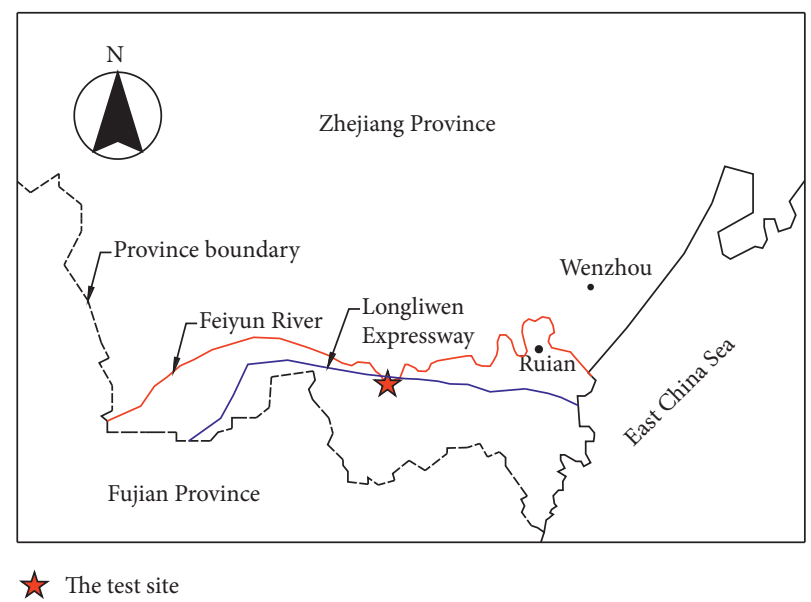

Figure 1: Distribution of the planned expressway in Zhejiang Province and location of test site.
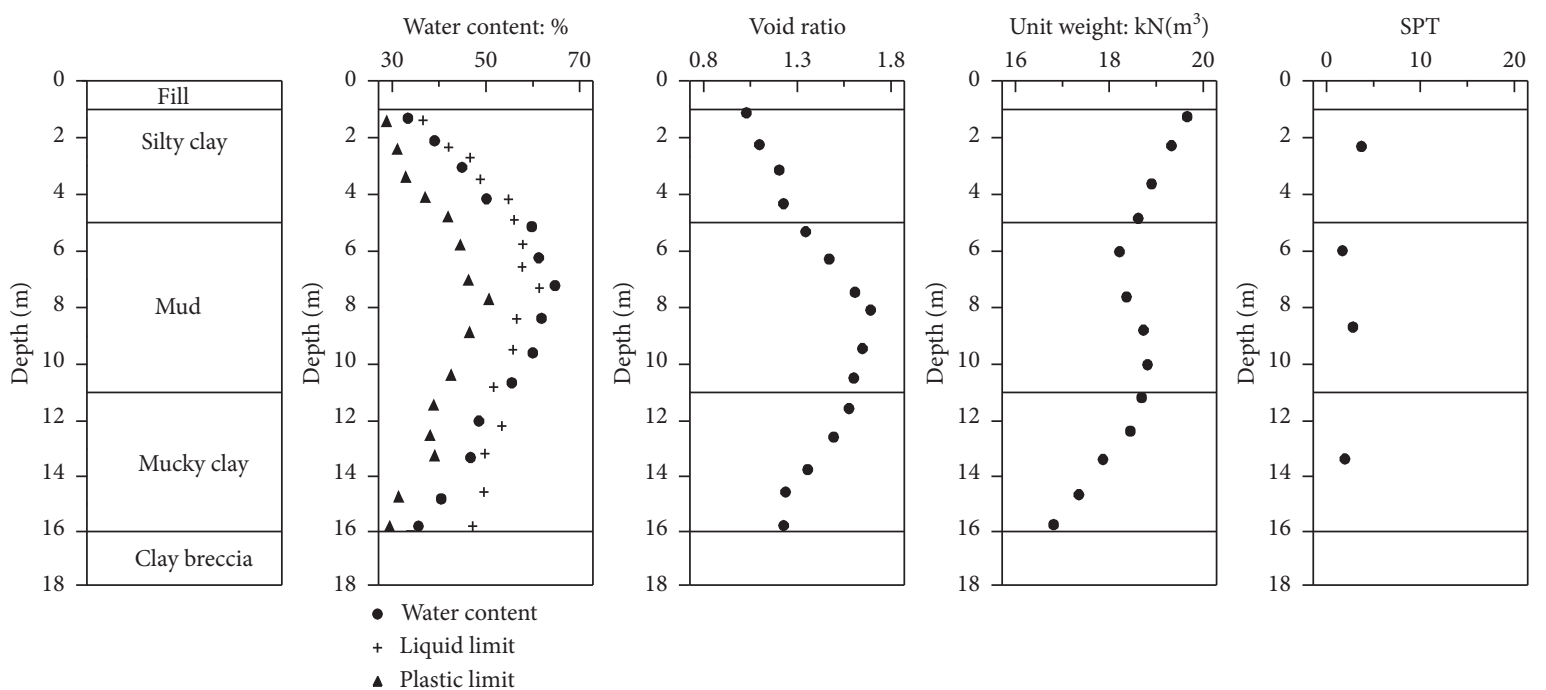

FIGURE 2: Geotechnical profiles and properties on-site.

embankment is evaluated by simplified Bishop method. The FOS can be determined by the following equations:

$$
\begin{aligned}
\text { FOS }= & \frac{\sum K_{i}}{\sum W_{i} \sin \alpha_{i}}, \\
K_{i}= & \frac{c_{d i} b_{i}+W_{d i} \tan \varphi_{d i}+U W_{t i} \tan \varphi_{d i}}{m_{a i}} \\
& \cdot(\text { soil }- \text { slice } i \text { in ground }), \\
K_{i}= & \frac{c_{t i} b_{i}+W_{t i} \tan \varphi_{t i}}{m_{a i}} \text { (soil - slice } i \text { in embankment), } \\
m_{a i}= & \frac{\cos \alpha_{i}+\sin \alpha_{i} \tan \varphi_{i}}{\operatorname{FOS}},
\end{aligned}
$$

where $W_{i}$ is the gravity of the soil-slice $i$ (as shown in Figure 4); $K_{i}$ is a factor; $\alpha_{i}$ is the horizontal angle of the soilslice $i$ (see Figure 4); $c_{d i}$ is the cohesion of the soil-slice $i$ in ground; $\varphi_{d i}$ is the friction angle of the soil-slice $i$ in ground; $W_{d i}$ is the gravity of the soil-slice $i$ in ground; $b_{i}$ is the width of the soil-slice $i$ (as shown in Figure 4); $W_{t i}$ is the gravity of the soil-slice $i$ in embankment; $c_{t i}$ is the cohesion of the soilslice $i$ in embankment; $\varphi_{t i}$ is the friction angle of the soil-slice $i$ in embankment; and $\varphi_{i}$ is the friction angle of the soil-slice $i$. Using the above analytical method, the FOS of this case history can be calculated as 1.8 , which is larger than the design requirement, 1.35 , and the safety of the embankment construction can also be verified by the measure displacement during the construction.

\section{Field Monitoring Program}

3.1. Monitoring Methods and Technical Requirements. The settlement of soft foundation was mainly observed by settlement plate. Observation points were laid on the middle line of the subgrade and the edge of the shoulder. Settlement was measured by leveling. Relying on the 


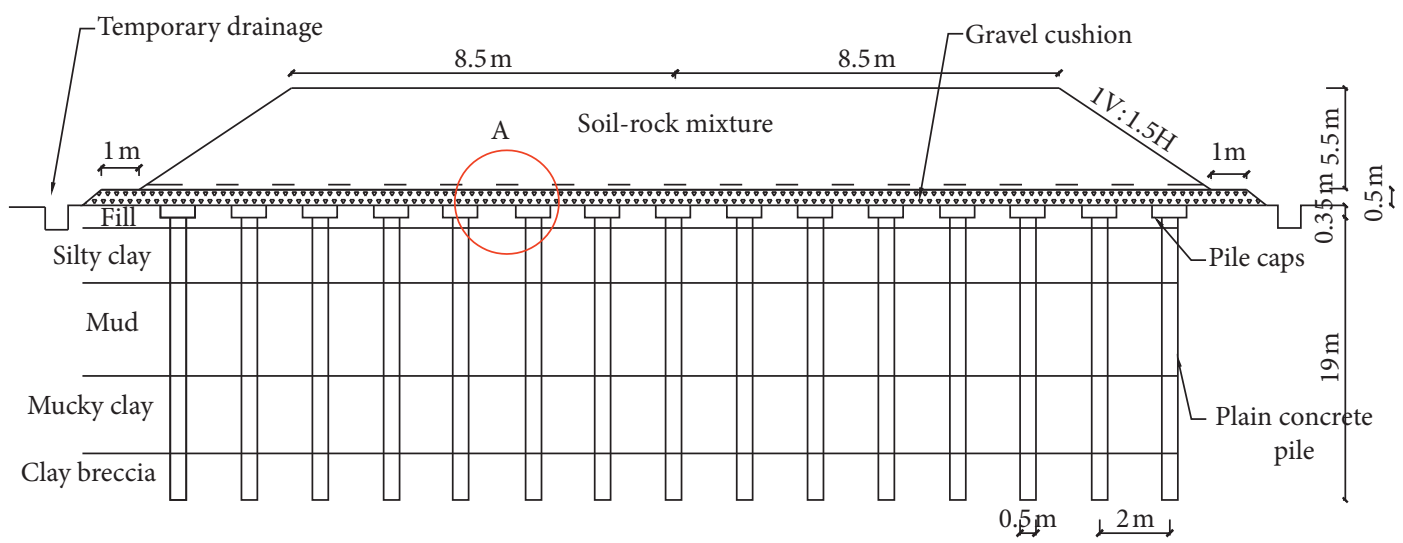

(a)

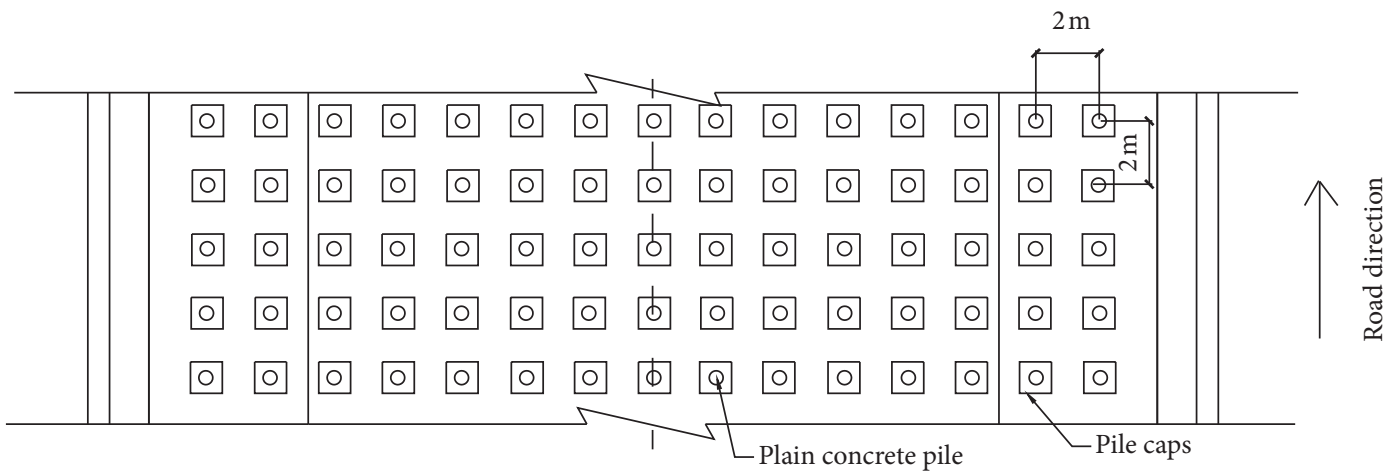

(b)

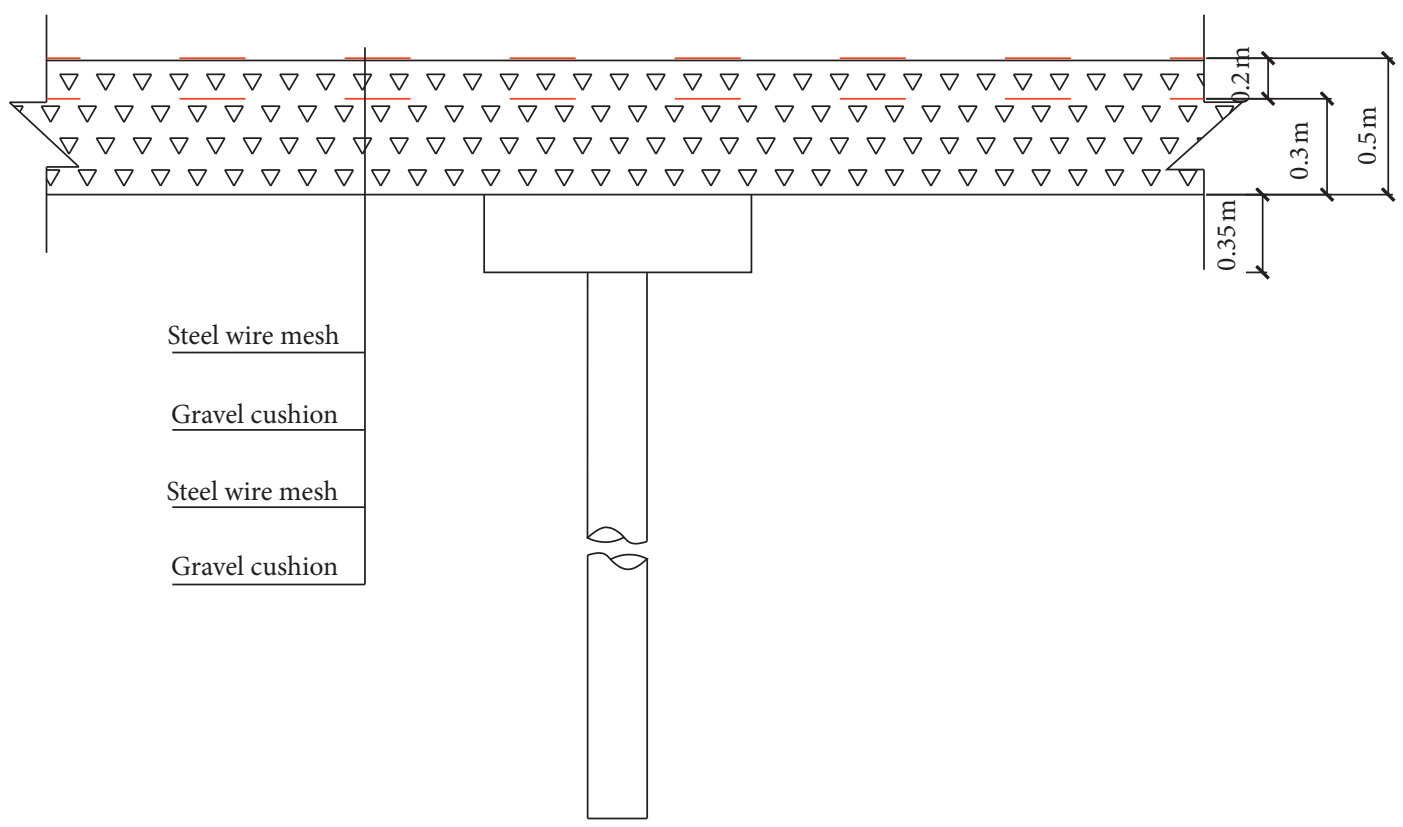

(c)

FiguRE 3: Embankment design and pile foundation reinforcement: (a) typical section diagram of soft foundation treated by plain concrete piles, (b) pile foundation plan layout, (c) detailed A section in (a).

construction control network, the monitoring and control network along the route was established. Based on the Code for Engineering Surveying, GB50026-2007 [36], deformation monitoring grade and accuracy requirements are shown in Table 1.
The settlement plate can be laid after soft foundation treatment and before embankment filling. Settlement plate base was made of steel plate of $50 \mathrm{~cm} \times 50 \mathrm{~cm} \times 0.50 \mathrm{~cm}$. The rod should be steel pipe or galvanized pipe, and the bottom rod should be welded with the settlement plate. The casing 


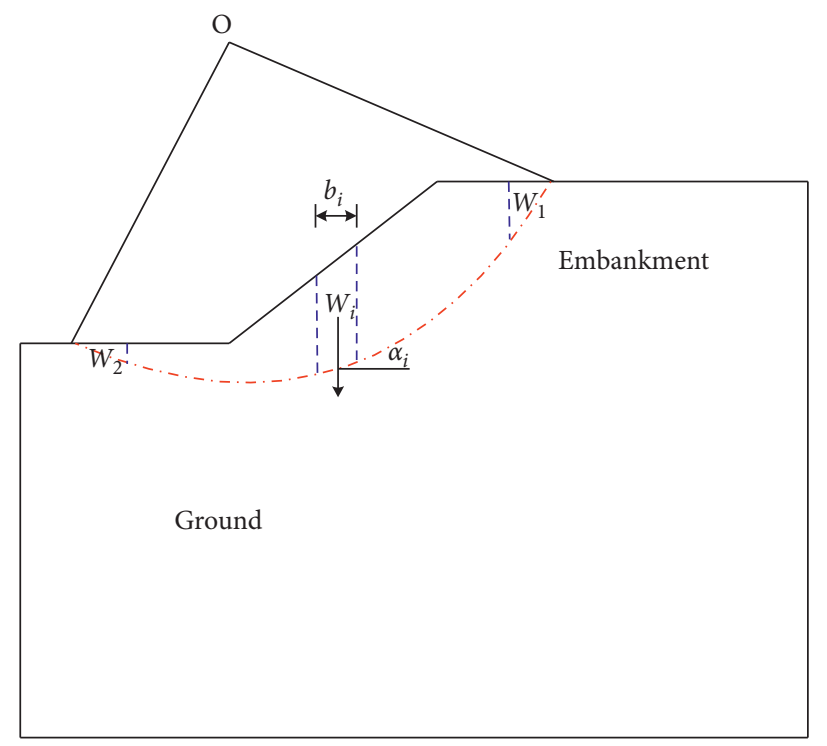

Figure 4: Schematic view of calculation of FOS by simplified Bishop method.

TABLE 1: Deformation monitoring grade and accuracy requirements.

\begin{tabular}{lccc}
\hline Grade & $\begin{array}{c}\text { Elevation medium error of } \\
\text { deformation observation points } \\
(\mathrm{mm})\end{array}$ & $\begin{array}{c}\text { Median error of height difference between } \\
\text { adjacent deformation observation points }(\mathrm{mm})\end{array}$ & $\begin{array}{c}\text { Median error of deformation } \\
\text { observation points }(\mathrm{mm})\end{array}$ \\
\hline $\begin{array}{l}\text { Third class } \\
\text { leveling }\end{array}$ & 1.0 & 0.5 & 6.0 \\
\hline
\end{tabular}

was plastic pipe. With the increase of filling soil, the measuring rod and casing were connected correspondingly, and the length of each section was generally $50 \mathrm{~cm}$. A small compactor was used to compact the soil around the settlement plate. When placing the settling plate, the bottom groove of the settling plate should be flat. Sand cushion should be laid under the settling plate. The vertical deviation rate of the connecting rod of the settlement plate and the bottom plate should be no more than $1.5 \%$.

Displacement monitoring adopted displacement pile (surface displacement) and inclinometer tube (deep soil displacement) for dynamic monitoring. The displacement piles were mainly used to monitor horizontal and vertical displacements. Horizontal displacement of measuring point can be achieved by polar coordinate method with high precision total station and prism. Vertical displacement can be observed by high precision level or total station with prism. The displacement side piles were laid before soft foundation treatment. They were prefabricated with reinforced concrete. The top of the pile should be pre-embedded with forced alignment facilities. When the displacement piles were placed in excavated soil, the pile body was poured and fixed with concrete from the bottom up to $50 \mathrm{~cm}$.

The inclinometer tube was formed by polyethylene casting. The outer diameter of the tube was $71 \mathrm{~mm}$ and the wall thickness is $6 \mathrm{~mm}$. It was buried in the deep section of soft soil and the front of bridge head. The burial depth should be no less than $1 \mathrm{~m}$ through the soft soil layer. The accuracy of the inclinometer system was not less than
$0.25 \mathrm{~mm} / \mathrm{m}$, and the resolution was not less than $0.02 \mathrm{~mm} / 500 \mathrm{~mm}$. The monitoring principle of the inclinometer used in monitoring is shown in Figure 5(b).

The horizontal deviation of the action point of the pulley under the probe relative to the action point of the upper pulley was calculated by the inclination angle $\theta$ measured by the instrument. The calculation formula is as follows:

$$
\text { (1) } \delta_{i}=L_{i} \times \sin \theta_{i}
$$

where $\delta_{i}$ is incremental value of relative horizontal deviation in Section 1 (the bottom of the inclinometer is Section 1); $L_{i}$ is vertical length of measuring in Section 1 ; and $\theta_{i}$ is relative increment of inclination in Section 1. Assuming that the horizontal deviation of the section is zero, the total horizontal deviation of the inclinometer at the depth of section $n$ is as follows:

$$
\text { (2) } \delta=\sum_{i=1}^{n} \Delta \delta_{i}=\sum_{i=1}^{n} L * \sin \Delta \theta_{i} \text {. }
$$

3.2. Control Standard and Monitoring Frequency. Based on the Chinese Design Code, JTG D30-2015 [34], the filling rate should be strictly controlled during the filling process of embankment in soft foundation section. The control standard was that the land subsidence rate of the embankment center line was not more than $1.0 \mathrm{~cm}$ per day and night. The horizontal displacement rate of slope foot was not more than 


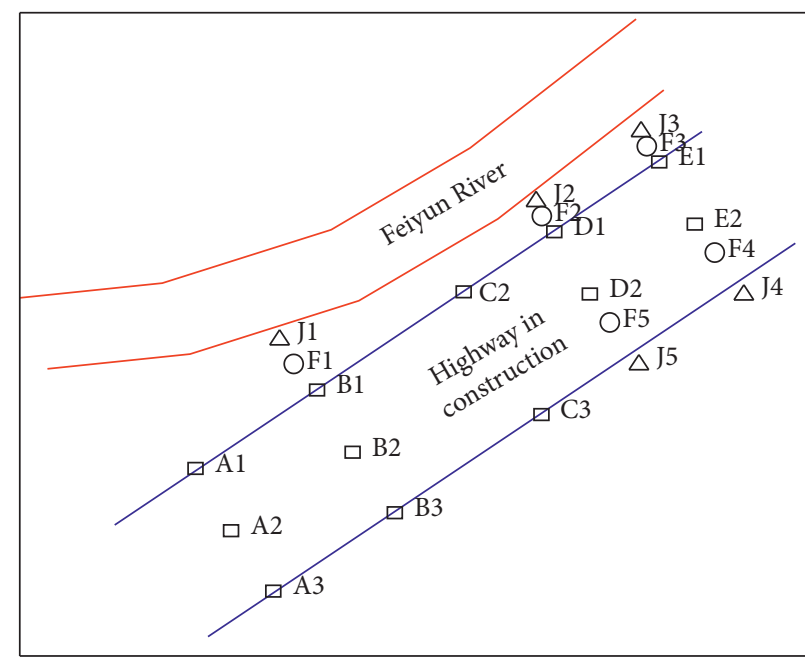

$\square$ Settlement plate A1, 2, 3; B1, 2, 3; C1, 2; D1, 2; E1, 2

Inclinometer tube $\mathrm{F} 1,2,3,4,5$

$\triangle$ Displacement pile J1, 2, 3, 4, 5

(a)

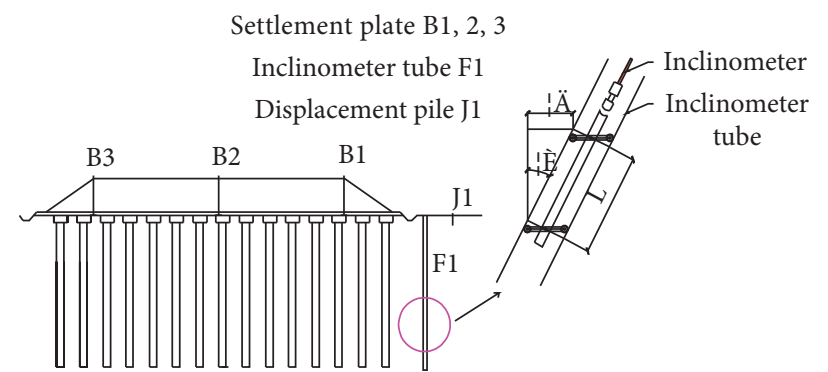

(b)

FIGURE 5: Site layout and instrumentation for field test: (a) plan view of the embankment monitoring facilities, (b) diagram of typical section monitoring facilities.

$0.5 \mathrm{~cm}$ per day and night. Deep lateral displacement rate was $3 \mathrm{~mm}$ per day and night. The settlement of the preloaded road section was less than $5 \mathrm{~mm}$ for two consecutive months. The monitoring frequency is summarized as follows:

(1) Construction period: at least one observation per floor was required. If the construction was stopped for any reason, it was observed every three days.

(2) Preloading period: observation every three days in the first month, observation every seven days from the second month to the third month, and observation every half a month from the fourth month until the pavement is paved.

(3) Operation period after construction: a small number of typical sections were taken for follow-up observation once every 1-2 months. The frequency of lateral displacement observation was the same as that of settlement observation until the embankment reached the designed construction elevation.

\section{Field Observations and Discussion}

4.1. Ground Settlement. The settlement observation of embankment section began with embankment filling. Figure 6 illustrates the relationship between the cumulative settlements of section A (A1, A2, A3), section B (B1, B2, B3), section $C(C 1, C 2)$, section $D(D 1, D 2)$, and section $E(E 1$, E2) with time. The settlement rate curves of the maximum accumulative settlement measurement points (A1, B1, C1, D1, E1) with time are also described.

The filling height at sections A and B was about $5.5 \mathrm{~m}$. The embankment was filled in layers with a thickness of $50 \mathrm{~cm}$. The filling work was divided into four stages. The first stage consisted of two layers of filling with a filling height of
$1 \mathrm{~m}$. It took 25 days to fill and 25 days to consolidate the soilrock mixture. The filling height of the latter three stages was $1.5 \mathrm{~m}$ with 25 days for filling and 30 days for consolidation. In the process of subgrade filling, the settlement of A and B had similar development law with time (Figures 6(a) and 6(b)). Firstly, when the first stage was filled to $1 \mathrm{~m}$, the maximum accumulative settlement of A1 and B1 was $5.53 \mathrm{~mm}$ and $6.02 \mathrm{~mm}$, respectively. In the second stage of filling to $2.5 \mathrm{~m}$, the maximum settlement of $\mathrm{A} 1$ and $\mathrm{B} 1$ was $13.77 \mathrm{~mm}$ and $14.85 \mathrm{~mm}$, respectively. When the third stage was filled to $4 \mathrm{~m}$, the maximum accumulated settlement occurred at A1 and B1, which was $23.72 \mathrm{~mm}$ and $26.80 \mathrm{~mm}$, respectively. Up to $5.5 \mathrm{~m}$ of filling, the maximum accumulative settlement of A1 and B1 was $26.23 \mathrm{~mm}$ and $29.78 \mathrm{~mm}$, respectively. This corresponded to $76 \%$ and $78 \%$ of the ultimate settlement. The filling height at sections C, D, and $\mathrm{E}$ was about $3 \mathrm{~m}$. The filling of three sections was constructed in three stages. Each stage was filled in two layers. The filling time was 25 days and the consolidation time was 30 days with $1 \mathrm{~m}$ filling height. When the first stage was filled to $1 \mathrm{~m}$, the maximum cumulative settlement of the three sections was $10.54 \mathrm{~mm}, 6.15 \mathrm{~mm}$, and $10.72 \mathrm{~mm}$ at C1, $\mathrm{D} 1$, and E1, respectively. When the second stage was filled to $2 \mathrm{~m}$, the accumulative settlement of $\mathrm{C} 1, \mathrm{D} 1$, and $\mathrm{E} 1$ was the largest with $18.31 \mathrm{~m}, 14.80 \mathrm{~mm}$, and $18.90 \mathrm{~mm}$, respectively. The accumulative settlements of C1, D1, and E1 were $18.96 \mathrm{~m}, 17.04 \mathrm{~mm}$, and $16.89 \mathrm{~mm}$, respectively, when filling to $3 \mathrm{~m}$, which were the largest values in each section. These values corresponded to $77 \%, 73 \%$, and $75 \%$ of the ultimate settlement. Finally, the accumulative settlements of A1, B1, $\mathrm{C} 1, \mathrm{D} 1$, and E1 tended to be stable, which were $34.33 \mathrm{~mm}$, $37.88 \mathrm{~mm}, 24.77 \mathrm{~mm}, 23.20 \mathrm{~mm}$, and $22.66 \mathrm{~mm}$, respectively. The filling stage was the main consolidation and deformation stage of the embankment $[37,38]$. The consolidation of 


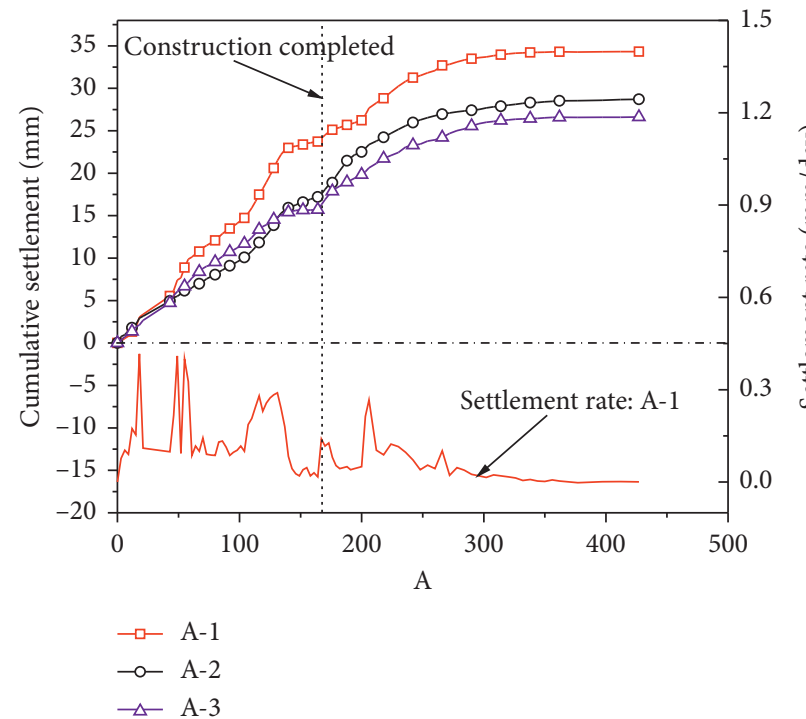

(a)

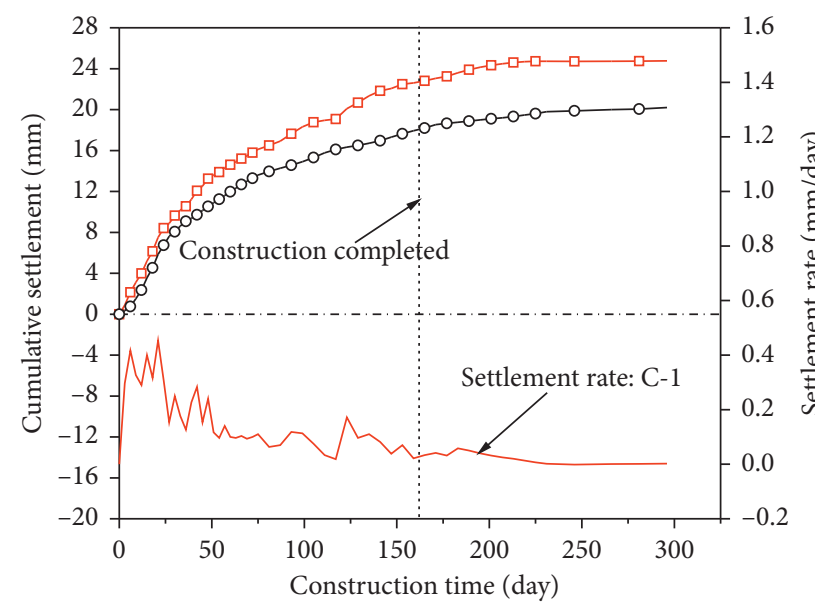

$\rightarrow$ C-1

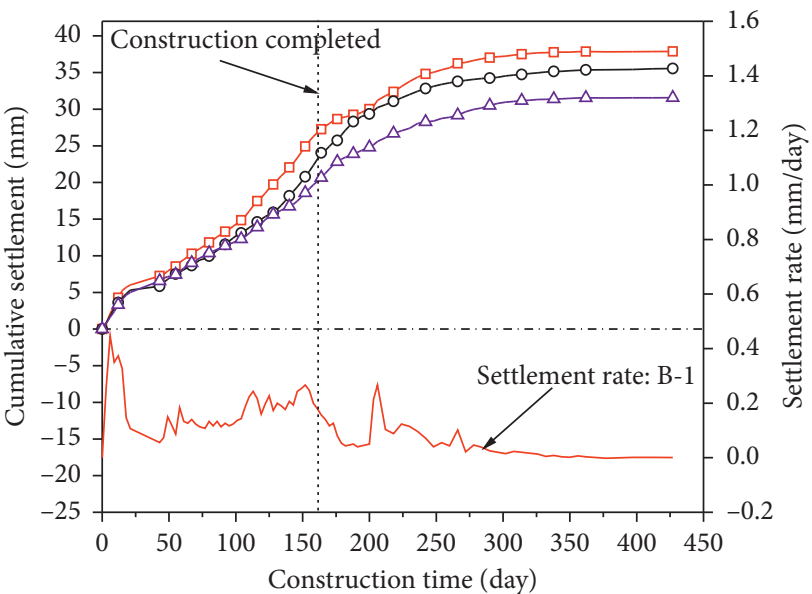

$\rightarrow-$ B-1

$\multimap$ B-2

$\triangle-$ B-3

(b)

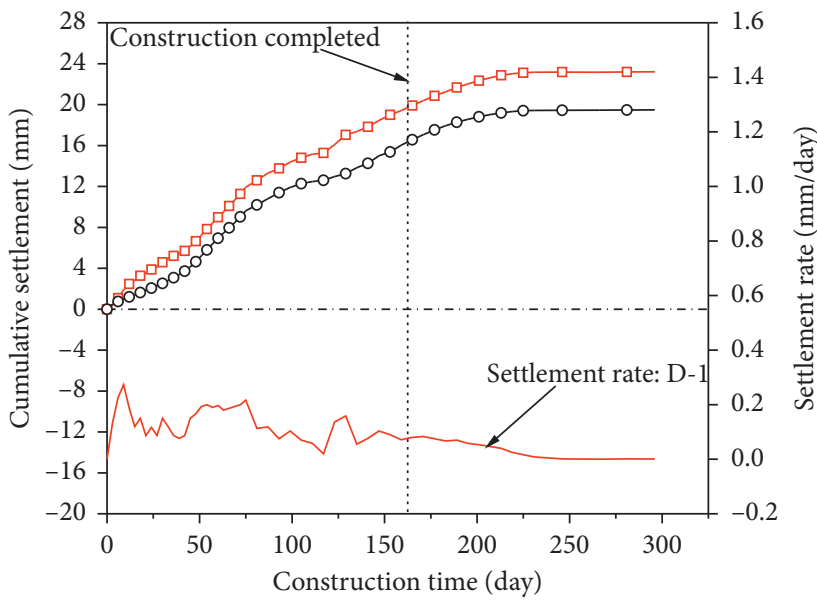

$\rightarrow-D-1$

$\multimap$ D-2

(d)

(c)

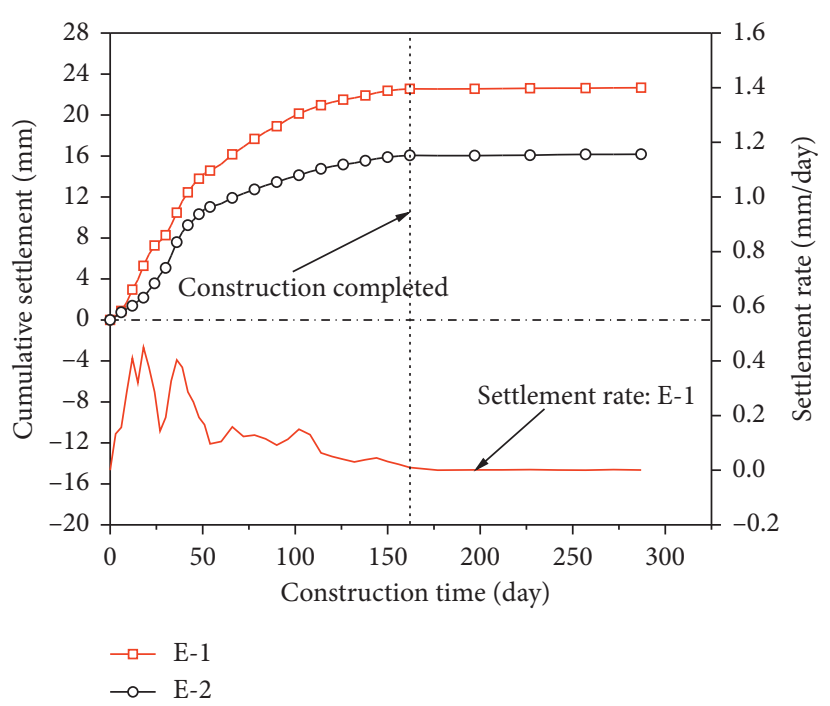

(e)

FIGURE 6: Cumulative ground settlement values of each monitoring section and settlement rate corresponding to the maximum cumulative settlement. 

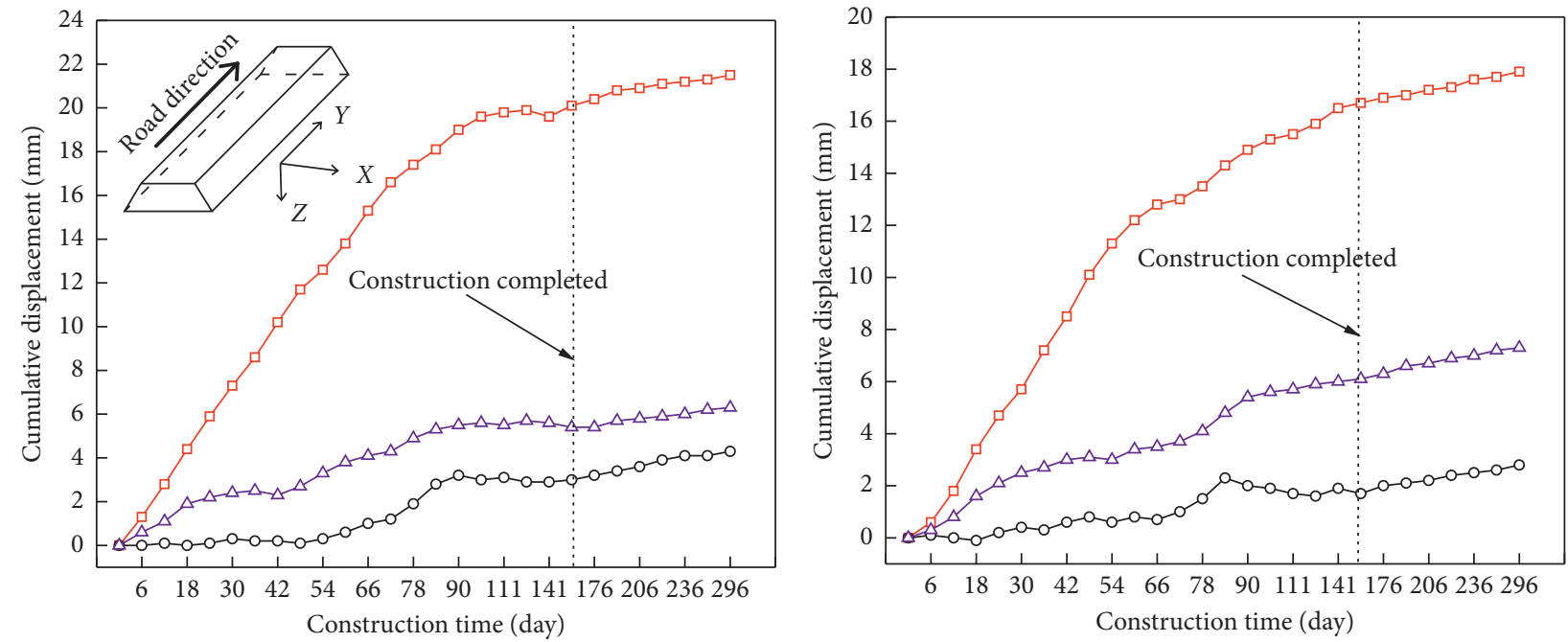

J1

$\mathrm{J} 2$

$\rightarrow \square$

$\multimap Y$

$\triangle Z$

(a)

(b)
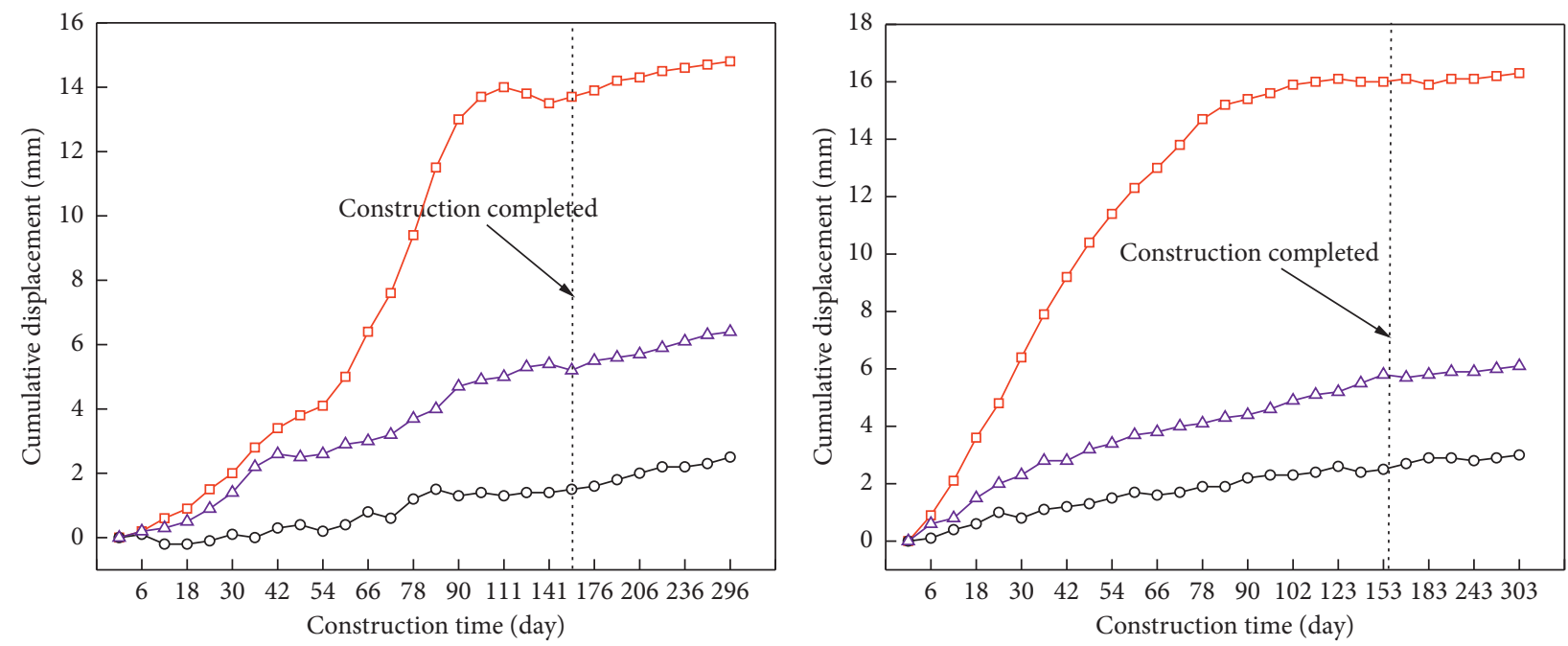

$\mathrm{J} 3$

J4

$\rightarrow-X$

$\multimap Y$

$\triangle-Z$

(c)

(d)

Figure 7: Continued. 


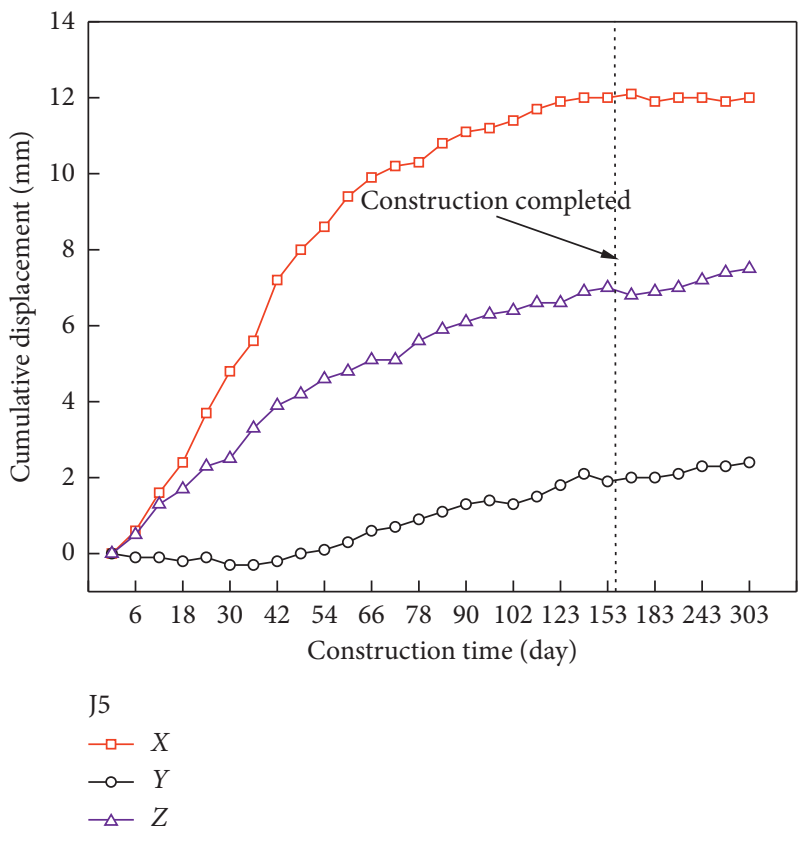

(e)

FIgURE 7: Cumulative ground displacement values of each monitoring point. Notes: $X$ : the positive value is that the measuring point moves away from the central axis of the subgrade, while the negative value is that the measuring point moves towards the central axis of the subgrade. $Y$ : the positive value is that the measuring point moves towards the end of the roadbed, while the negative value is that the measuring point moves towards the beginning of the roadbed. $Z$ : the positive value is sinking and the negative value is uplift.

soil is the largest, which accounted for a considerable part of the total settlement. When the filling height was reached, the load gradually became stable. With the drainage consolidation of foundation soil, the strength of soil gradually increased, and the cumulative settlement-time curve of subgrade tended to be flat. At this time, the settlement was mainly secondary consolidation. And the settlement converged to a stable value which was the final settlement. Figure 5 also shows that the settlement rate of A1, B1, C1, D1, and E1 points increased sharply during filling period and tended to be flat during consolidation period. The maximum settlement rates were $0.42 \mathrm{~mm} /$ day, $0.37 \mathrm{~mm} /$ day, $0.42 \mathrm{~mm} /$ day, $0.27 \mathrm{~mm} /$ day, and $0.45 \mathrm{~mm} /$ day, respectively, which were within the control range.

The maximum cumulative settlement of each section occurred at the location near the riverside on the left side of the subgrade (Figure 4). According to the site geographic environment and geological conditions, the role of the river had a certain impact on the stability of the embankment [39-41]. Based on the Chinese design code, JTG D30-2015 [34], the monitoring results showed that the maximum cumulative settlement and settlement rate did not exceed the control range. It can be seen that the composite foundation composed of plain concrete pile and reinforced cushion plays an important role in improving the stability of embankment. With the increase of filling height of subgrade, the cumulative ground settlement values will become larger, but the settlement rate will be smaller because of the continuous consolidation of soil.
4.2. Ground Displacement. Figure 6 shows the change of accumulated surface displacement of each observation point during the observation period. Displacement piles (J1, J2, J3, J4, J5) were buried outside the treatment scope of soft soil roadbed. Moreover, the cumulative displacement of five displacement piles had similar law with time. With the increase of embankment filling height, the cumulative displacement increased gradually. The displacement tended to be stable after the final filling was completed. The ultimate cumulative displacement of each measuring point in the $X$ direction was relatively large, which was $21.5 \mathrm{~mm}$ (J1), $17.9 \mathrm{~mm}$ (J2), $15.2 \mathrm{~mm}$ (J3), $16.3 \mathrm{~mm}$ (J4), and $12.0 \mathrm{~mm}$ (J5), respectively. The reason may be that, in the direction perpendicular to the route, the lateral soil body of the embankment was not restrained. The filling increased the load, which resulted in large deformation in this direction. As can be seen, the ultimate cumulative displacement in the $Y$ direction was the smallest, which was $2.5 \mathrm{~mm}$ (J1), $2.8 \mathrm{~mm}$ (J2), $4.3 \mathrm{~mm}$ (J3), $3.0 \mathrm{~mm}$ (J4), and $2.4 \mathrm{~mm}$ (J5), respectively. Because the filling height of the embankment on the section where the displacement pile (J1) was located is about twice that of other measuring points, and the equivalent load was nearly twice that of other measuring points, the accumulated lateral displacement of the ground surface was relatively large. However, due to the reinforcement effect of the pile, there is not much difference between the maximum displacement and the minimum displacement. Figure 7 also illustrates that the displacement pile (J3) may have a steeper curve change rate due to the rapid filling in the filling process, where the displacement rate was relatively large. 

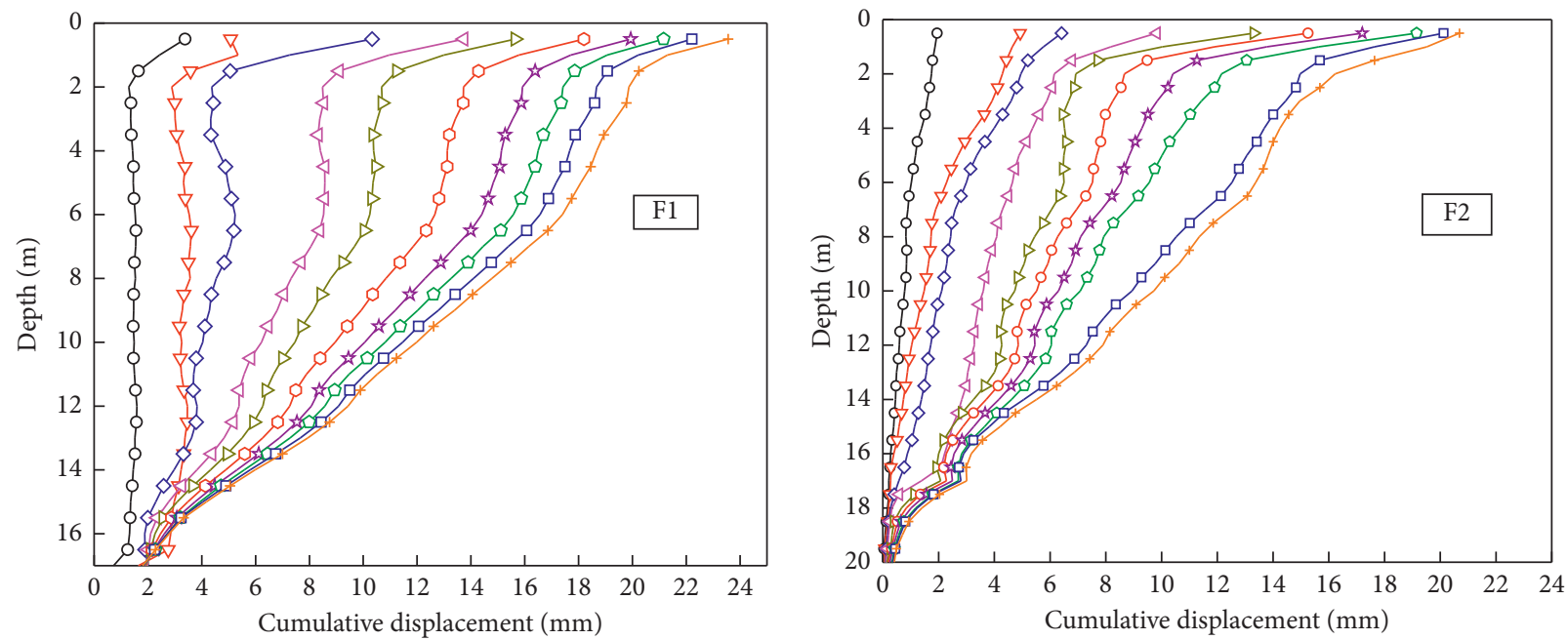

Time

- -30 day

$$
\begin{array}{ll}
\rightarrow-150 \text { day } & \multimap-240 \text { day } \\
\neg-180 \text { day } & \rightarrow-270 \text { day } \\
\rightarrow-210 \text { day } & \longrightarrow 300 \text { day }
\end{array}
$$

$\rightarrow-60$ day

$\checkmark-90$ day

$\neg 120$ day

\begin{tabular}{|c|c|c|}
\hline$-0-30$ day & $\rightarrow-150$ day & $\neg-240$ day \\
\hline$-\nabla-60$ day & -o- 180 day & $\rightarrow-270$ day \\
\hline$\checkmark 90$ day & $\rightarrow \leftarrow 210$ day & $\longrightarrow 300$ day \\
\hline
\end{tabular}

(a)

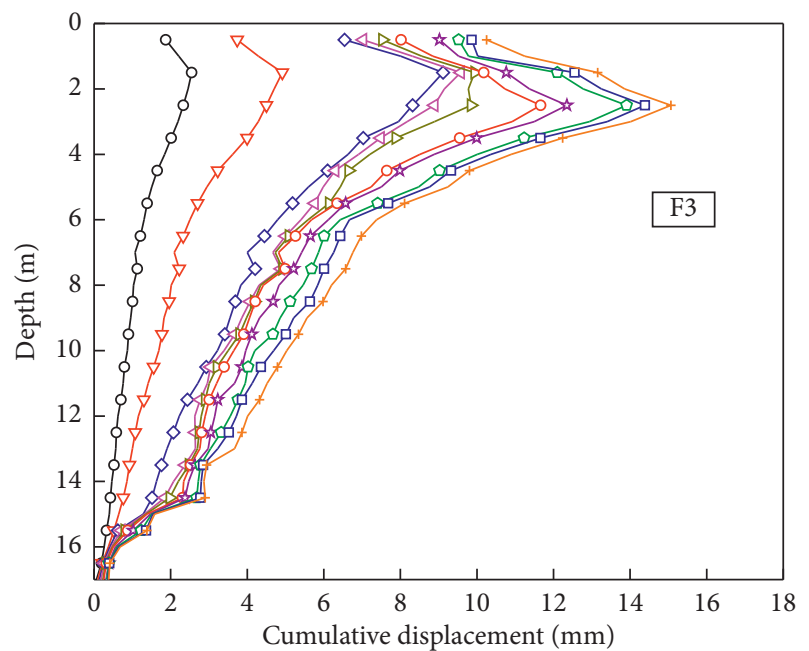

\begin{tabular}{|c|c|c|}
\hline$-0-30$ day & $\rightarrow-150$ day & $\neg \sim-240$ day \\
\hline$-\nabla-60$ day & $-0-180$ day & $\neg-270$ day \\
\hline$\prec-90$ day & $\rightarrow \longrightarrow 210$ day & +300 day \\
\hline
\end{tabular}

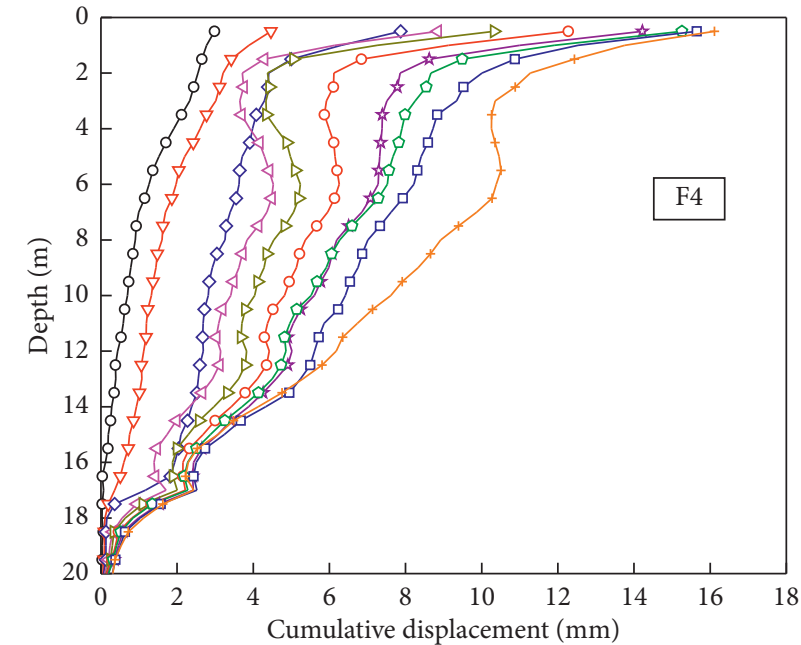

Time

Time

(c)

(d)

Figure 8: Continued. 


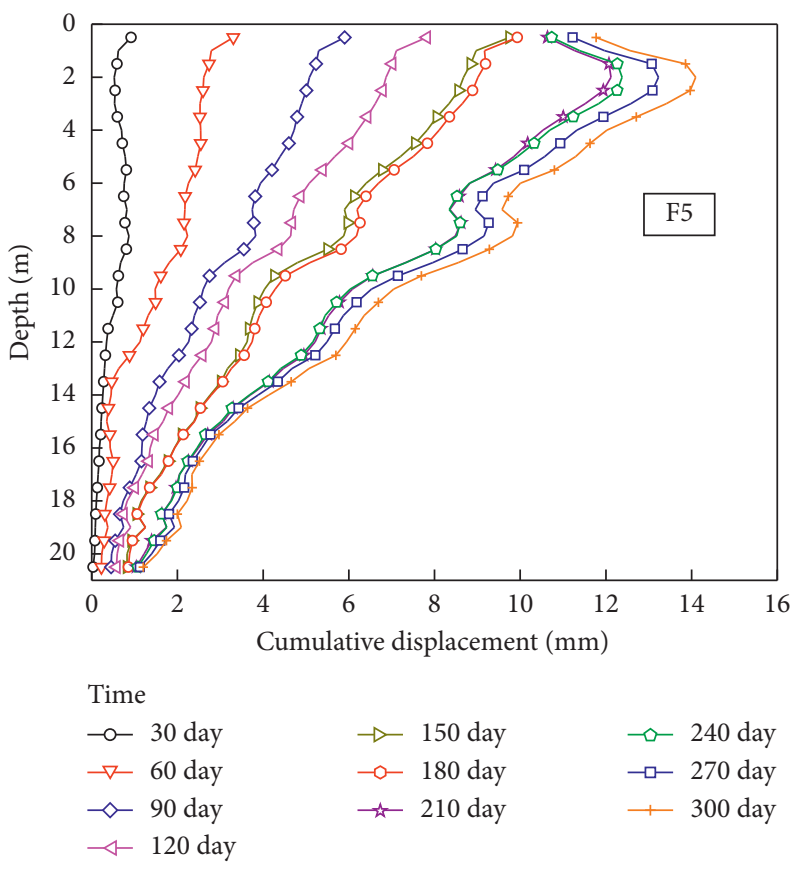

(e)

FIGURE 8: Lateral displacement of subsoil of each measuring point.

With the completion of embankment filling, the load gradually stabilized. Lateral surface displacement also decreased gradually, and the displacement curve tended to be flat.

4.3. Lateral Displacement of Subsoil. Figure 8 shows the variation of horizontal displacement in the depth of each survey point. It was measured by an inclinometer at $2 \mathrm{~m}$ from the foot of embankment slope. The maximum cumulative lateral displacements of inclinometer tubes (F1, F2, and F4) were $23.56 \mathrm{~mm}, 20.68 \mathrm{~mm}$, and $16.11 \mathrm{~mm}$, respectively, which all occurred at $0.5 \mathrm{~mm}$ below the surface. The maximum cumulative lateral displacement of subsoil of the inclined pipe (F3) was $14.01 \mathrm{~mm}$, which occurred at a depth of $3 \mathrm{~m}$ below the surface, while the maximum cumulative lateral displacement of subsoil of the inclined pipe (F5) was $14.10 \mathrm{~mm}$, which occurred at a depth of $2 \mathrm{~m}$ below the surface. Among them, the cumulative displacement of the inclinometer tube (F2) was the largest, which was mainly related to the embankment filling height. During embankment filling, the maximum cumulative displacement of each measuring point accounted for 75\%,73\%, 78\%, 76\%, and $64 \%$ of the final cumulative displacement, respectively. Therefore, the process of loading caused large displacement of embankment. It can be seen from the data of each monitoring point that the lateral displacement inside the soil was relatively small. From the bottom of the inclinometer tube to the ground, the lateral displacement of soil increases gradually. And the closer the ground, the greater the displacement. It also shows that the treatment of soft soil subgrade played a vital role in the stability of embankment. Embankment construction or excavation process involves a time-dependent problem due to the dissipation of excess pore water pressure $[42,43]$. Due to the fact that the pore water pressure indicators were all destroyed because of the carelessness of construction persons during the construction, the time-dependent behavior of this project was not given more focus.

\section{Conclusions}

A case study for highway construction over soft marine clay in China is presented in this paper. The obtained results from this study are summarized as follows:

(1) The settlement on the left side of the embankment was larger than that on the right side. The final cumulative settlement of each section near the river side was the largest, which was $34.33 \mathrm{~mm}, 37.88 \mathrm{~mm}$, $24.77 \mathrm{~mm}, 23.20 \mathrm{~mm}$, and $22.66 \mathrm{~mm}$, respectively. During the embankment filling, the settlement accounted for $76 \%, 78 \%, 77 \%, 73 \%$, and $75 \%$ of the final settlement. The maximum settlement rate was $0.45 \mathrm{~mm} /$ day. With the increase of embankment filling height, the cumulative settlement has an increase. When the embankment construction was completed, the settlement gradually tended to be stable.

(2) The maximum displacement of the surface at the distance of $2.5 \mathrm{~m}$ away from the foot of the embankment was $21.5 \mathrm{~mm}$. The filling height of this section was twice that of other sections, and the load was also nearly twice that of other sections, which makes the lateral displacement of the surface larger. However, due to the reinforcement effect of plain concrete pile and reinforced cushion on roadbed, the observed displacements were not different. 
(3) The maximum cumulative horizontal displacement of each monitoring point was $23.56 \mathrm{~mm}$, which occurred at $0.5 \mathrm{~mm}$ below the surface. Moreover, the displacement generated during embankment filling accounted for about $75 \%$ of the final displacement. The smallest percentage of other monitoring sites was $64 \%$. It can be seen that the filling had a certain impact on the embankment. The measured settlement and displacement meet the specification requirement, and the monitoring of the process should be strengthened to ensure the safety of the construction.

\section{Data Availability}

The data used to support the findings of this study are included within the article.

\section{Conflicts of Interest}

The authors declare that they have no conflicts of interest.

\section{Acknowledgments}

This research was funded by the China Postdoctoral Science Foundation (Grant nos. 2016M600396 and 2017T100355). Partial financial support from the Fundamental Research Funds for the Central Universities (Grant no. B200204001) is also acknowledged.

\section{References}

[1] S.-L. Shen, Y.-J. Du, and C.-Y. Luo, "Evaluation of the effect of rolling correction of double-o-tunnel shields via one-side loading," Canadian Geotechnical Journal, vol. 47, no. 10, pp. 1060-1070, 2010.

[2] Z.-F. Wang, S.-L. Shen, C.-E. Ho, and Y.-H. Kim, "Investigation of field-installation effects of horizontal twin-jet grouting in Shanghai soft soil deposits," Canadian Geotechnical Journal, vol. 50, no. 3, pp. 288-297, 2013.

[3] X. Bian, L.-L. Zeng, J.-W. Ding, and S. Qian, "Assessment of the effects of initial water contents on the pore pressure response of reconstituted clays," European Journal of Environmental and Civil Engineering, vol. 21, no. 4, pp. 454-470, 2017.

[4] X. Bian, Y.-J. Cui, and X.-Z. Li, "Voids effect on the swelling behaviour of compacted bentonite," Géotechnique, vol. 69, no. 7, pp. 593-605, 2019.

[5] Z. Hong, S. Liu, S. Shen, and T. Negami, "Comparison in undrained shear strength between undisturbed and remolded ariake clays," Journal of Geotechnical and Geoenvironmental Engineering, vol. 132, no. 2, pp. 272-275, 2006.

[6] A. M. C. Horbe, I. R. da Trindade, E. L. Dantas, R. V. Santos, and M. Roddaz, "Provenance of quaternary and modern alluvial deposits of the Amazonian floodplain (Brazil) inferred from major and trace elements and $\mathrm{Pb}-\mathrm{Nd}-\mathrm{Sr}$ isotopes," Palaeogeography, Palaeoclimatology, Palaeoecology, vol. 411, pp. 144-154, 2014.

[7] X. Bian, Z.-F. Wang, G.-Q. Ding, and Y.-P. Cao, "Compressibility of cemented dredged clay at high water content with super-absorbent polymer," Engineering Geology, vol. 208, pp. 198-205, 2016.
[8] H. B. Nagaraj, M. V. Sravan, and B. S. Deepa, "Factors influencing undrained strength of fine-grained soils at high water contents," Geomechanics and Geoengineering, vol. 13, no. 4, pp. 276-287, 2018.

[9] X. S. Shi and J. Zhao, "Practical estimation of compression behavior of clayey/silty sands using equivalent void-ratio concept," Journal of Geotechnical and Geoenvironmental Engineering, vol. 146, no. 6, Article ID 4020046, 2020.

[10] W.-C. Cheng, G. Li, N. Liu, J. Xu, and S. Horpibulsuk, "Recent massive incidents for subway construction in soft alluvial deposits of Taiwan: a review," Tunnelling and Underground Space Technology, vol. 96, Article ID 103178, 2020.

[11] X. Bian, Y.-J. Cui, L.-L. Zeng, and X.-Z. Li, "Swelling behavior of compacted bentonite with the presence of rock fracture," Engineering Geology, vol. 254, pp. 25-33, 2019.

[12] X. Bian, Y.-J. Cui, L.-L. Zeng, and X.-Z. Li, "State of compacted bentonite inside a fractured granite cylinder after infiltration," Applied Clay Science, vol. 186, Article ID 105438, 2020.

[13] W.-C. Cheng, J. C. Ni, A. Arulrajah, and H.-W. Huang, “A simple approach for characterising tunnel bore conditions based upon pipe-jacking data," Tunnelling and Underground Space Technology, vol. 71, pp. 494-504, 2018.

[14] H. L. Liu, C. W. W.M. Ng, and K. Fei, "Performance of a geogrid-reinforced and pile-supported highway embankment over soft clay: case study," Journal of Geotechnical and Geoenvironmental Engineering, vol. 133, no. 12, pp. 14831493, 2007.

[15] Z. F. Wang, W. C. Cheng, Y. Q. Wang, and J. Q. Du, "Simple method to predict settlement of composite foundation under embankment," International Journal of Geomechanics, vol. 18, no. 12,2018

[16] W.-C. Cheng, J. C. Ni, H.-W. Huang, J. S. Shen, and J. S. Shen, "The use of tunnelling parameters and spoil characteristics to assess soil types: a case study from alluvial deposits at a pipejacking project site," Bulletin of Engineering Geology and the Environment, vol. 78, no. 4, pp. 2933-2942, 2019.

[17] W.-C. Cheng, L. Wang, Z.-F. Xue, J. C. Ni, M. M. Rahman, and A. Arulrajah, "Lubrication performance of pipejacking in soft alluvial deposits," Tunnelling and Underground Space Technology, vol. 91, Article ID 102991, 2019.

[18] H. Wang, L. L. Zeng, X. Bian, and Z. S. Hong, "Train moving load-induced vertical superimposed stress at ballasted railway tracks," Advances in Civil Engineering, vol. 2020, Article ID 3428395, 11 pages, 2020.

[19] S. L. Shen, C. Y. Luo, Y. Bai, Y. H. Kim, and S. J. Peng, "Instant solidification of soft ground horizontally using jet-grouting," in Contemporary Topics in Ground Modification, Problem Soils, and Geo-Support, pp. 257-264, American Society of Civil Engineers (ASCE) Press, Reston, VA, USA, 2009.

[20] Z. F. Wang, J. S. Shen, and W. C. Cheng, "Simple method to predict ground displacements caused by installing horizontal jet-grouting columns," Mathematical Problems in Engineering, vol. 2018, Article ID 1897394, 11 pages, 2018.

[21] J.-J. Chen, L. Zhang, J.-F. Zhang, Y.-F. Zhu, and J.-H. Wang, "Field tests, modification, and application of deep soil mixing method in soft clay," Journal of Geotechnical and Geoenvironmental Engineering, vol. 139, no. 1, pp. 24-34, 2013.

[22] A. S. A. Rashid, A. R. Bunawan, and K. N. Mat Said, "The deep mixing method: bearing capacity studies," Geotechnical and Geological Engineering, vol. 35, no. 4, pp. 1271-1298, 2017.

[23] M. Saberian, M. Moradi, R. Vali, and J. Li, "Stabilized marine and desert sands with deep mixing of cement and sodium 
bentonite," Geomechanics and Engineering, vol. 14, no. 6, pp. 553-562, 2018.

[24] J. L. Briaud, R. Abdelmalak, X. Zhang, and C. Magbo, "Sztiffened slab-on-grade on shrink-swell soil: new design method," Journal of Geotechnical and Geoenvironmental Engineering, vol. 142, no. 7, Article ID 4016017, 2016.

[25] M. A. Shams, M. A. Shahin, and M. A. Ismail, "Simulating the behaviour of reactive soils and slab foundations using hydromechanical finite element modelling incorporating soil suction and moisture changes," Computers and Geotechnics, vol. 98, pp. 17-34, 2018.

[26] Y. Lv, H. Liu, X. Ding, and G. Kong, "Field tests on bearing characteristics of X-section pile composite foundation," Journal of Performance of Constructed Facilities, vol. 26, no. 2, pp. 180-189, 2012.

[27] A. R. Vosoughi, P. Malekzadeh, and H. Razi, "Response of moderately thick laminated composite plates on elastic foundation subjected to moving load," Composite Structures, vol. 97, pp. 286-295, 2013.

[28] M. Ehrlich, S. H. Mirmoradi, and R. P. Saramago, "Evaluation of the effect of compaction on the behavior of geosyntheticreinforced soil walls," Geotextiles and Geomembranes, vol. 34, pp. 108-115, 2012.

[29] M. Ghazavi and J. Nazari Afshar, "Bearing capacity of geosynthetic encased stone columns," Geotextiles and Geomembranes, vol. 38, pp. 26-36, 2013.

[30] R. Girout, M. Blanc, L. Thorel, and D. Dias, "Geosynthetic reinforcement of pile-supported embankments," Geosynthetics International, vol. 25, no. 1, pp. 37-49, 2018.

[31] R. P. Chen, Y. W. Wang, X. W. Ye, X. C. Bian, and X. P. Dong, "Tensile force of geogrids embedded in pile-supported reinforced embankment: a full-scale experimental study," Geotextiles and Geomembranes, vol. 44, no. 2, pp. 157-169, 2016.

[32] R. Xu and B. Fatahi, "Geosynthetic-reinforced cushioned piles with controlled rocking for seismic safeguarding," Geosynthetics International, vol. 25, no. 6, pp. 561-581, 2018.

[33] ASTM Standard D2487, Standard Practice for Classification of Soils for Engineering Purposes (Unified Soil Classification System), American Society for Testing and Materials, West Conshohocken, PA, USA, 2011.

[34] Ministry of Transport of the People's Republic of China, Technical Specifications for Construction of Highway Subgrades (JTG/T 3610-2019), China Communications Press, Beijing, China, 2019.

[35] Ministry of Housing and Urban-Rural Development of the People's Republic of China, Technical Code for Testing of Building Foundation Piles, China Architecture \& Building Press, Beijing, China, 2014.

[36] Ministry of Construction of the People's Republic of China, Code for Engineering Surveying (GB50021-2007), China Architecture and Building Press, Beijing, China, 2008.

[37] F. Tavenas and S. Leroueil, "The behaviour of embankments on clay foundations," Canadian Geotechnical Journal, vol. 17, no. 2, pp. 236-260, 1980.

[38] A. S. Al-Homoud and N. Tanash, "Monitoring and analysis of settlement and stability of an embankment dam constructed in stages on soft ground," Bulletin of Engineering Geology and the Environment, vol. 59, no. 4, pp. 259-284, 2001.

[39] C. Swartenbroekx, S. Soares-Frazão, R. Staquet, and Y. Zech, "Two-dimensional operator for bank failures induced by water-level rise in dam-break flows," Journal of Hydraulic Research, vol. 48, no. 3, pp. 302-314, 2010.

[40] H. Mizutani, H. Nakagawa, T. Yoden, K. Kawaike, and H. Zhang, "Numerical modelling of river embankment failure due to overtopping flow considering infiltration effects," Journal of Hydraulic Research, vol. 51, no. 6, pp. 681-695, 2013.

[41] Y.-Q. Wang, Z.-F. Wang, and W.-C. Cheng, "A review on land subsidence caused by groundwater withdrawal in Xi'an, China," Bulletin of Engineering Geology and the Environment, vol. 78, no. 4, pp. 2851-2863, 2019.

[42] D. E. L. Ong, C. F. Leung, Y. K. Chow, and T. G. Ng, "Severe damage of a pile group due to slope failure," Journal of Geotechnical and Geoenvironmental Engineering, vol. 141, no. 5, Article ID 4015014, 2015.

[43] Z.-F. Wang, S.-L. Shen, G. Modoni, and A. Zhou, "Excess pore water pressure caused by the installation of jet grouting columns in clay," Computers and Geotechnics, vol. 125, Article ID 103667, 2020. 